\title{
The Influence of Starvation and Eurytrema Coelomaticum Infection on the Nitrogenous Products of Degradation in the Hemolymph of Bradybaena Similaris
}

\author{
Rosana M. de Souza, Edna M. Gomes ${ }^{1}$, Generoso M. Chagas ${ }^{1}$ and Jairo Pinheiro ${ }^{1 *}$ \\ ${ }^{1}$ Universidade Federal Rural do Rio de Janeiro, Instituto de Biologia, Departamento de Ciências Fisiológicas, km \\ 47 da Antiga Estrada Rio-Sâo Paulo, Seropédica - RJ, Brazil
}

\begin{abstract}
The urea and uric acid contents in the hemolymph of Bradybaena similaris were analyzed under starvation and Eurytrema coelomaticum infection during 30 days. The urea and uric acid contents in the uninfected and fed snails were $15.090 \mathrm{mg} / \mathrm{dl}$ and $9.399 \mathrm{mg} / \mathrm{dl}$, respectively, being the urea/uric acid ratio 1.6 . The urea content in starved snails increased to a maximum of $363.237 \mathrm{mg} / \mathrm{dl}$ at 15 days, and the uric acid varied to a maximum of $11.470 \mathrm{mg} / \mathrm{dl}$. The urea content in infected snails was reduced to a minimum of $2.123 \mathrm{mg} / \mathrm{dl}$ at 30 days of infection and the uric acid increased significatively at 25 days post exposure, being $13.820 \mathrm{mg} / \mathrm{dl}$. A significative relation was not observed between the time of starvation and time of $\mathrm{E}$. coelomaticum infection and the uric acid content in the hemolymph of $\mathrm{B}$. similaris.
\end{abstract}

Key words: Urea, uric acid, starvation, Bradybaena similaris, Eurytrema coelomaticum, host-parasite relationship

\section{INTRODUCTION}

The snail Bradybaena similaris (Fèrussac, 1821) is a gastropod widely distributed throughout Brazil (Araújo, 1989), being a plague to the horticulture and used as intermediate host for many parasites, such as Eurytrema coelomaticum and Angiostrongylus costaricensis, acquiring economic, medical and veterinary importance. The effects of the starvation on the carbohydrate deposits in B. similaris has been studied (Pinheiro, 1996) and it was observed that at 30 days of starvation, the main deposits of carbohydrates were reduced on average $80 \%$. Other authors observed alterations in the nitrogenous products of degradation metabolism in snails in response to the alterations that occurred during starvation (Becker \& Schmale, 1975; Schmale \& Becker, 1975). Becker (1980) observed that urea concentration increased during starvation and larval trematode infection in Biomphalaria glabrata, but the concentration of ammonia did not vary significantly. Becker (1983) did study the alterations in the uric acid and guanine in the tissues of $B$. glabrata under starvation and

*Author for correspondence
Schistosoma mansoni infected and he observed an increase of these purines concentration. Thus, the nitrogenous products of degradation under physiological conditions of stress may be altered that would cause in the snail an intoxication by the excess of these products.

The objective of this to study was determine the alterations in the content of the nitrogenous products of degradation that occur in $B$. similaris hemolymph during starvation.

\section{MATERIAL AND METHODS}

Snails collection and maintenance: Specimens of Bradybaena similaris were manually collected from lettuce and mint leaves of gardens located at km 9, BR465, Seropédica, RJ, Brazil and transported to the laboratory. All the snails were examined through their transparent shell to verify the presence of Postharmostomum gallinum metacercariae in the pericardial cavity. Samples of the snails were randomly chosen and dissected to verify the presence of other larva in its soft tissues.

Starvation establishment: The snails free of infection were maintained in plastic vivaria with 
earth at the bottom and moistened with tap water in alternate days and fed ad libitum with cabbage leaves (Brassica sp.) for a week. After this time, groups of 25 snails were formed and submitted to $5,10,15,20,25$ and 30 days of starvation, where the food supply was interrupted and only water was provided to them to prevent dehydration. Another group of $B$. similaris was fed ad libitum and maintained as a control group.

Experimental infections: Adults of $E$. coelomaticum were collected from pancreas of bovines naturally infected and slaughtered at the Matadouro de Cacaria, Seropédica, RJ, Brazil, and incubated in Locke's saline solution (Humason, 1979) overnight and the eggs laid were collected, washed in distilled water and maintained at $10^{\circ} \mathrm{C}$ until further use. Pieces of cabbage leaves were put in the Petri dishes covered at the bottom with filter paper, and eggs of E. coelomaticum were transferred to them with a Pasteur pipette. The snails were left in contact with the eggs in a dose of 10 eggs/snail, approximately, overnight. After this time, the snails were separated in seven groups 0 (control group), 5, 10, 15, 20, 25 and 30 days of infection and maitained as described above.

Biochemical determinations: At the end of each period of starvation and E. coelomaticum infection, the hemolymphs of 25 snails were collected by punction of pericardial cavity, under stereomicroscope, using a syringe (Plastipak B-D ${ }^{\circledR}$ ) and frozen until its utilization. The urea content in the haemolymph of B. similaris was determined accordingly to Fawcett \& Scott (1960) and the uric acid content was determined accordingly to Barham \& Trinder (1972). All the biochemical determinations were made in triplicate.

Statistical analysis: The values obtained in different periods of starvation and infection were expressed in mean $(\mathrm{X})$ and standard deviation (SD). The difference observed among the values obtained in the periods of starvation were analyzed statistically with Tukey test $(P<0,05)$. The significance of the relation between the starvation and the infection and urea and uric acid content in the hemolymph of $B$. similaris was determined through polinomial regression analysis (Graph Pad, Prism Inc.)

\section{RESULTS AND DISCUSSION}

According to Bishop et al. (1983) in the terrestrial species of molluscs the most of nitrogenous products of degradation were excreted as urea or uric acid and other purine compounds. But, in the terrestrial snails under normal conditions, the urea excretion is a process more advantageous than uric acid excretion, once that the urea can be excreted highly dilluted avoiding the intoxication of the snail. Our results showed that the urea content in the hemolymph of $B$. similaris under normal conditions was higher than the uric acid content, indicating that the urea is the principal nitrogenous product excreted by this specie, being the ratio urea:uric acid 1.6

The urea content in the fed and uninfected snails (control group) was $15.09 \mathrm{mg} / \mathrm{dl}$. The urea content in the in the hemolymph of B. similaris starved increased $2.392 \%$ at 15 days of starvation, but this increase was less at the end of the starvation period studied. Tukey's test showed a significant variation through the period analyzed (Table 1).

The polinomial regression analysis revealed a positive relation between the time of starvation and the urea content in the hemolymph of $B$. similaris (Fig. 1). In the infected snails, the urea content was significantly reduced ranging the lowest value at the end of the period of infection studied, being reduced in $86 \%$. The comparison of the mean values obtained showed a minor variation during the period analyzed than that observed during the starvation (Table 2). The polinomial regression analysis showed a significant negative relation between the time of $E$. coelomaticum infection and the urea content in the hemolymph of B. similaris (Fig. 2). 
Table 1. Urea content in the hemolymph of Bradybaena similaris, expressed in $\mathrm{mg} / \mathrm{dl}$, under starvation (day), and its percentual increase through the 30 days of starvation.

\begin{tabular}{cccc}
\hline $\begin{array}{c}\text { Time of starvation } \\
\text { (days) }\end{array}$ & $\begin{array}{c}\text { Urea content } \\
(\mathbf{m g} / \mathbf{d l}) \\
\mathbf{X} \pm \mathbf{S D}\end{array}$ & $\mathbf{M}$ & $\begin{array}{c}\text { Percentual } \\
\text { increase }\end{array}$ \\
\hline 0 (control group) & $15.090 \pm 3,020^{\mathrm{a}}$ & 75 & 0 \\
05 & $141.139 \pm 6,038^{\mathrm{b}, \mathrm{d}}$ & 75 & 935 \\
10 & $132.587 \pm 9,949^{\mathrm{b}}$ & 75 & 879 \\
15 & $363.237 \pm 38,802^{\mathrm{c}}$ & 75 & 2.392 \\
20 & $355.730 \pm 17,390^{\mathrm{c}}$ & 75 & 2.357 \\
25 & $181.866 \pm 1,621^{\mathrm{d}}$ & 75 & 1.205 \\
30 & $199.057 \pm 4,720^{\mathrm{d}}$ & 75 & 1.319 \\
\hline
\end{tabular}

$\mathrm{X}=$ mean of three biochemical determinations

$\mathrm{SD}=$ standard deviation.

$\mathrm{M}=$ number of snails used.

Different letters indicate means with significant difference among them $(\alpha=5 \%)$.

Table 2. Urea content in the hemolymph of Bradybaena similaris, expressed in $\mathrm{mg} / \mathrm{dl}$, experimentaly infected with Eurytrema coelomaticum (days), and its percentual reduction through 30 days of infection.

\begin{tabular}{cccc}
\hline $\begin{array}{c}\text { Time of infection } \\
\text { (days) }\end{array}$ & $\begin{array}{c}\text { Urea content } \\
(\mathbf{m g} / \mathbf{d l}) \\
\mathbf{X} \pm \mathbf{S D}\end{array}$ & $\mathbf{M}$ & $\begin{array}{c}\text { Percentual } \\
\text { reduction }\end{array}$ \\
\hline 0 (control group) & $15.090 \pm 3,020^{\mathrm{a}}$ & 75 & 0 \\
05 & $8.802 \pm 0,976^{\mathrm{b}}$ & 75 & 42 \\
10 & $2.199 \pm 1,445^{\mathrm{c}, \mathrm{d}}$ & 75 & 85 \\
15 & $4.042 \pm 1,419^{\mathrm{b}, \mathrm{d}}$ & 75 & 73 \\
20 & $4.495 \pm 1,677^{\mathrm{b}, \mathrm{d}}$ & 75 & 70 \\
25 & $5.090 \pm 3,100^{\mathrm{b}, \mathrm{d}}$ & 75 & 66 \\
30 & $2.123 \pm 1,252^{\mathrm{c}, \mathrm{d}}$ & 75 & 86 \\
\hline
\end{tabular}

$\mathrm{X}=$ mean of three biochemical determinations

$\mathrm{SD}=$ standard deviation.

$\mathrm{M}=$ number of snails used.

Different letters indicate means with significant difference among them $(\alpha=5 \%)$.

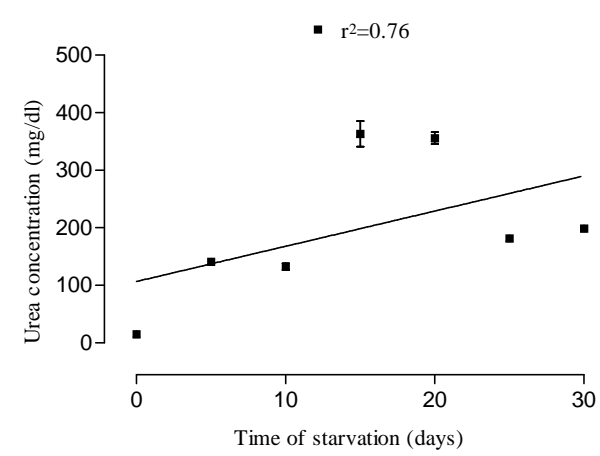

Figure 1. Relation between the urea content in the hemolymph of Bradybaena similaris $(\mathrm{mg} / \mathrm{dl})$ and the period of starvation (days).

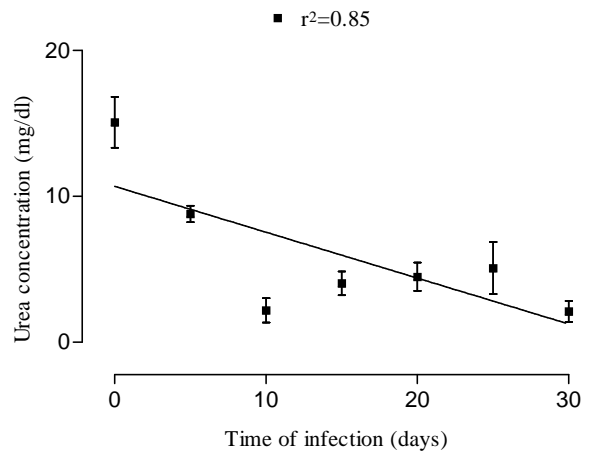

Figure 2. Relation between the urea content in the hemolymph of Bradybaena similaris $(\mathrm{mg} / \mathrm{dl})$ and the time of Eurytrema coelomaticum infection (days). 
Both situations studied caused a depletion of nutrients in the animal, but the starvation was more drastic than the trematode infection, because the larval trematodes used the carbohydrates as the main source of substrate to obtain energy to the intense plastic processes that occurred during its intramolluscan development. The parasites drained the nutrients slowly from host and the snail continued to get food, these factors attenuate this condition allowing to snail adpat itself to alterations that occur in consequence of parasitism. Pinheiro \& Amato (1994) observed that in the snail $B$. similaris infected with E. coelomaticum the glucose content in the hemolymph was reduced in more than $60 \%$ and the deposits of glycogen were reduced in $90 \%$ at the end of pre-patent period. Pinheiro (1996) observed that under starvation B.similaris has a reduction higher than $80 \%$ in its carbohydrate reserves of cephalopedal mass, digestive gland and albumen gland. Other authors have shown similar effects in snails under starvation and trematode infected with reduction in the glucose level in the hemolymph and depletion of the carbohydrates reserves (Cheng \& Lee, 1971; Friedle, 1971; Lee \& Gheng, 1972; Ishak et al., 1975; Michelson \& Dubois, 1975; Manohar \& Rao, 1976; Teng et al., 1979; Joosse \& van Elk, 1986; Crews \& Yoshino, 1990). According to Meyer et al. (1986) because of the withdrawal of nutrients from the hemolymph snail by growing parasites, the effect of a trematode infection resembled that of a short period of starvation. Under these situations, the concentration of those products that could be used as a substrate in the energetic metabolism decreased (Lee \& Cheng, 1972; Stanislawsky et al., 1979; Trede \& Becker, 1982). The intense catabolisation of protein reported by Becker (1980; 1983) lead the snail to an increase in the urea production and excretion.

In spite of the general idea about the uricotelism in the terrestrial snails, in our study a small variation was observed in the uric acid content in the hemolymph of $B$. similaris during $E$. coelomatiucum infection, where the concentration of this product was increased in $47 \%$ at the 25 days of starvation, this being the only values significantly different among the other (Table 3), but at the end of the period of infection studied this variation showed a reduction of $1.6 \%$. These observations are similar to that of Becker (1983), where the uric acid content in B. glabrata infected with Schistosoma mansoni was increased to a maximum on day 40 post infection and decrease afterwards.

The polinomial regression showed a significant positive relation $\left(r^{2}=0,71\right)$ between the time of infection with $E$. coelomaticum and the the uric acid content in the hemolymph of $B$. similaris (Fig. 3). During the 30 days of starvation studied it was observed a variation higher than that occured in the E. coelomaticum infection, being the major increase observed at 10 days of starvation (25\%) and major reduction observed at 20 days of starvation (20\%) (Table 4). No significant relation was observed between the time of starvation and the uric acid concentration in the hemolymph of $B$. similaris $\left(\mathrm{r}^{2}=0.07\right)$ (Fig. 4).

The results obtained showed that the uric acid content varied less than urea in the hemolymph of $B$. similaris in both physiological conditions studied. The starvation and the E. coelomaticum infection caused a depletion of carbohydrate reserves of the snail and it needed to use other substrate to obtain the energy to its maintenance and survival. According to Becker (1980) total proteins and free amino acids in the hemolymph of B. glabrata starved and Schistosoma mansoni infected were significantly reduced. This showed that the proteins and free amino acids might be used by the snails as an alternative source of energy under conditions of physiological stress as cited above.

The intense metabolisation of the proteins and amino acids caused an increase of the nitrogenous products of degradation in the snail body. But, the results obtained in the presente study must be analyzed carefully. The immediate result of this increased degradation of nitrogenous substrates, as proteins and amino acids, to obtain energy, was due to an increase in the ammonia production, but this did not occur in B. similaris under starvation (Lira, 1998). Speeg \& Campbell (1968) showed that in molluscs living under conditions of water limitation the purines accumulation was available, once that the urea occurred with a high loss of water. In our experiments, the snails lived under conditions with excess of water, which might explain why no significant accumulation of uric acid in both situations analyzed was observed. 
Table 3. Uric acid content in the hemolymph of Bradybaena similaris, expressed in $\mathrm{mg} / \mathrm{dl}$, experimentally infected with Eurytrema coelomaticum (days) and its percentual variation through the 30 days of infection.

\begin{tabular}{cccc}
\hline $\begin{array}{c}\text { Time of infection } \\
\text { (days) }\end{array}$ & $\begin{array}{c}\text { Uric acid content } \\
(\mathbf{m g} / \mathbf{d l})\end{array}$ & $\mathbf{M}$ & $\begin{array}{c}\text { Percentual } \\
\mathbf{X} \pm \mathbf{S D}\end{array}$ \\
\hline 0 (control group) & $9.399 \pm 0,446^{\mathrm{a}}$ & 75 & 0 \\
05 & $11.033 \pm 1,040^{\mathrm{a}}$ & 75 & $+17 \%$ \\
10 & $12.915 \pm 2,162^{\mathrm{a}}$ & 75 & $+37 \%$ \\
15 & $12.412 \pm 1,028^{\mathrm{a}}$ & 75 & $+32 \%$ \\
20 & $11.049 \pm 1,790^{\mathrm{a}}$ & 75 & $+18 \%$ \\
25 & $13.820 \pm 2,154^{\mathrm{b}}$ & 75 & $+47 \%$ \\
30 & $9.251 \pm 0,050^{\mathrm{a}}$ & 75 & $-1,6 \%$ \\
\hline
\end{tabular}

$\mathrm{X}=$ mean of three biochemical determinations

$\mathrm{SD}=$ standard deviation.

$\mathrm{M}=$ number of snails used.

Different letters indicate means with significant difference among them $(\alpha=5 \%)$.

Table 4. Uric acid content in the hemolymph of Bradybaena similaris, expressed in $\mathrm{mg} / \mathrm{dl}$, under starvation (days), and its percentual variation through the 30 days of starvation.

\begin{tabular}{cccc}
\hline $\begin{array}{c}\text { Time of starvation } \\
\text { (days) }\end{array}$ & $\begin{array}{c}\text { Uric acid content } \\
(\mathbf{m g} / \mathbf{d l}) \\
\mathbf{X} \pm \mathbf{S D}\end{array}$ & $\mathbf{M}$ & $\begin{array}{c}\text { Percentual } \\
\text { variation }\end{array}$ \\
\hline 0 (control group) & $9.399 \pm 0,446^{\mathrm{a}, \mathrm{e}}$ & 75 & 0 \\
05 & $8.438 \pm 0,365^{\mathrm{a}, \mathrm{c}, \mathrm{e}}$ & 75 & $-10 \%$ \\
10 & $11.761 \pm 0,975^{\mathrm{b}, \mathrm{d}}$ & 75 & $+25 \%$ \\
15 & $9.892 \pm 0,834^{\mathrm{a}, \mathrm{d}, \mathrm{e}}$ & 75 & $+5 \%$ \\
20 & $7.509 \pm 0,225^{\mathrm{c}}$ & 75 & $-20 \%$ \\
25 & $11.470 \pm 0,189^{\mathrm{d}, \mathrm{e}}$ & 75 & $+22 \%$ \\
30 & $10.695 \pm 0,656^{\mathrm{e}}$ & 75 & $+14 \%$ \\
\hline
\end{tabular}

$\mathrm{X}=$ mean of three biochemical determinations

$\mathrm{SD}=$ standard deviation.

$\mathrm{M}=$ number of snails used.

Different letters indicate means with significant difference among them $(\alpha=5 \%)$.

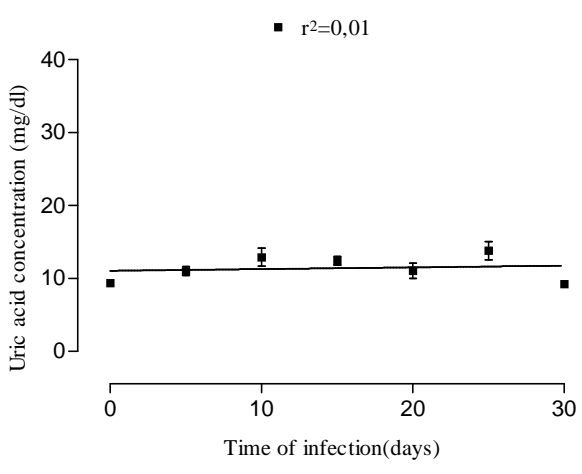

Figure 3. Relation between the uric acid content in the hemolymph of Bradybaena similaris $(\mathrm{mg} / \mathrm{dl})$ and the time of Eurytrema coelomaticum infection (days).

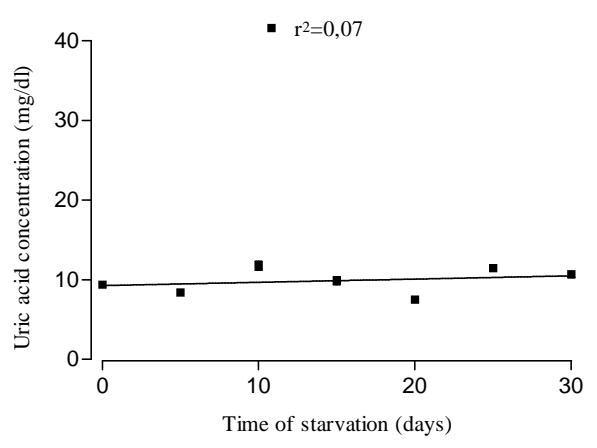

Figure 4. Relation between the uric acid content in the hemolymph of Bradybaena similaris ( $\mathrm{mg} / \mathrm{dl}$ ) and the period of starvation (days). 
The uric acid content in the hemolymph was higher in the trematode infected snails than in the starved snails at 30 days of analysis. The uric acid that has been formed is more toxic to the snail than the urea. Studies have shown that the starvation causes drastic alterations when compared to those alterations observed in the same period of trematode infection. Thus, the exceeding nitrogen came from the proteins and amino acids metabolism can not be excreted as uric acid, being excreted as urea in the starved snails, resulting in an significative increase of the content of urea and a non significantive variation of the uric acid content in the hemolymph of $B$. similaris during the starvation.

The trematode E. coelomaticum has a complex life cycle where the snail is its first intermediate host, in which it evolves until the second generation sporocyst stage. This step of the development of the parasite takes at about 100 days, so the period of 30 days of infection analyzed may not reflect the alterations in its major amplitude. But the objective of this study was to compare the alterations that occurred in the snail in 30 days of starvation and trematode infection.

\section{RESUMO}

O conteúdo de uréia e de ácido úrico na hemolnfa de Bradybaena similaris foi analisado em função da inanição e da infecção com Eurytrema coelomaticum ao longo de 30 dias. O conteúdo destas substâncias em moluscos não infectados e alimentados foi, respectivamente, $15.090 \mathrm{mg} / \mathrm{dl} \mathrm{e}$ $9.399 \mathrm{mg} / \mathrm{dl}$, sendo a relação uréia/ácido úrico 1.6. A concentração de uréia nos moluscos em inanição aumentou até um valor máximo de $363.237 \mathrm{mg} / \mathrm{dl}$, aos 15 dias de inanição e o conteúdo de ácido úrico variou até um valor máximo de 11.761 $\mathrm{mg} / \mathrm{dl}$, aos 10 dias de jejum. A concentração de uréia em moluscos infectados foi reduzida até um valor mínimo $2.123 \mathrm{mg} / \mathrm{dl}$, aos 30 dias de infecção, e o conteúdo de ácido úrico aumentou significativamente aos 25 dias de infecção, sendo $13.820 \mathrm{mg} / \mathrm{dl}$. Não foram observadas relações significativas entre o tempo de inanição e o tempo de infecção com estágios larvais de $E$. coelomaticum e o conteúdo de ácido úrico na hemolinfa de $B$. similaris.

\section{REFERENCES}

Araújo, J. L. de B. (1989), Moluscos de importância econômica no Brasil. I. Xanthonychidae: Bradybaena similaris (Férussac, 1821) (Mollusca, Gastropoda, Pulmonata, Stylommatophora). Revta. Bras. Zool., 6, 583-592.

Barham, D. \& Trinder, P. (1972), An improved colour reagent for determination of blood glucose by the oxidase system. Analyst, 97, 142-145.

Baudoin, M. (1975), Host castration as a parasitic strategy. Evolution, 29, 335-352.

Becker, W. (1980), Metabolic interrelationship of parasitic trematodes and molluscs, especially Schistosoma mansoni in Biomphalaria glabrata. Z. Parasitenkd., 63, 101-111.

Becker, W. (1983), Purine metabolism in Biomphalaria glabrata under starvation and infection with Schistosoma mansoni. Comp. Biochem. Physiol., 76B, 215-219.

Becker, W. \& Schmale, H. (1975), The nitrogenous products of degradation - ammonia, urea and uric acid - in the hemolymph of the snail Biomphalaria glabrata. Z. Parasitenkd., 51A, 407-411.

Bishop, S. H.; Ellis, L. L. \& Burcham, J. M. (1983), Amino acid metabolism in molluscs. In - The Mollusca. Metabolic Biochemistry and Molecular Biomechanics. v.1, Academic Press, New York, USA. 243-327.

Cheng, T. C. \& Lee, F. O. (1971), Glucose levels in the mollusc Biomphalaria glabrata infected with Schistosoma mansoni. J. Invert. Pathol., 18, 395-399.

Crews, A. E. \& Yoshino T. P. (1990), Influence of larval schistosomes on polysaccharide synthesis in albumin glands of Biomphalaria glabrata. Parasitol., 101, 351-359.

Fawcett, J. K. \& Scott, J. E. (1960), A rapid and precise method for determination of urea. J. Clin. Pathol., 13, 156-159.

Friedle, F. E. (1971), Hemolymph glucose in the freshwater pulmonate snail Lymnaea stagnalis: basal values and an effect of ingested carbohydrate. Comp Biochem. Physiol., 39A, 605-610.

Humason, G. L. (1979), Animal Tissue Techniques. $4^{\text {th }}$ ed., San Francisco, CA, USA: W. H Freeman and Company.

Ishak, M. M.; Mohamed, A. M. \& Sharaf, A. A. (1975), Carbohydrate metabolism in uninfected and trematode-infected snails Biomphalaria alexandrina and Bulinus truncatus. Comp. Biochem. Physiol., 51B, 499-505.

Lira, C. R. S. de. (1998), Efeitos da inanição sobre a concentração de proteínas totais e amônio na hemolinfa de Bradybaena similaris. Monografia. Universidade Federal Rural do Rio de Janeiro, Seropédica, RJ, Brasil. 
Joosse, J. \& Van Elk, R. (1986), Trichobilharzia ocellata: physiological characterization of giant growth, glycogen depletion, and absence of reproductive activity in the intermediate snail host, Lymnaea stagnalis. Exp. Parasitol., 62, 1-13.

Lee, F. O. \& Cheng, T. C. (1972), Schistosoma mansoni: alterations in total protein and hemoglobin in the hemolymph of infected Biomphalaria glabrata. Exp. Parasitol., 31, 203-216.

Manohar, L. \& Rao, P. V. (1976), Physiological response to parasitism. I. Changes in carbohydrate reserves of tme molluscan host. Southeast Asian J. Trop. Med. Public Health, 7, 395-404.

Meyer, R.; Becker, W. \& Klimkewitz, M. (1986), Investigations on the ketone body metabolism in Biomphalaria glabrata: influence of starvation and of infection with Schistosoma mansoni. J. Comp. Physiol. B, 156, 563-571.

Michelson, E. H. \& Dubois, E. H. (1975), Intraspecific variation in the hemolymph of Biomphalaria glabrata, a snail host of Schistosoma mansoni. Malacologia, 51, 478-484.

Pinheiro, J. (1996), Influence of starvation on the glycogen and galactogen contents in the snail Bradybaena similaris (Férussac, 1821) (Mollusca, Gastropoda). Arq. Biol. Tecnol., 39, 349-357.

Pinheiro, J. \& Amato, S. B. (1994), Eurytrema coelomaticum (Digenea, Dicroceliidae): the effect of infection on carbohydrate contents of its intermediate snail host, Bradybaena similaris (Gastropoda, Xanthnychidae). Mem. Inst. Oswaldo Cruz, 89, $407-$ 410.
Pinheiro, J. \& Amato, S. B. (1995), Eurytrema coelomaticum: Influence of the infection on the reproduction and nucleic acid contents in the albumn gland and ovotestis of Bradybaena similaris. Mem. Inst. Oswaldo Cruz, 90, 635-68.

Schmale, H. \& Becker, W. (1975), Die Ammoniumund Harnstoff-konzentration in der Hämolymphe von Biomphalaria glabrata unter dem Einflu $\beta$ einer Infektion mit Schistosoma mansoni. Z. Parasitenkd., 45, 237-241.

Speeg, K. V. Jr \& Campbell, J. W. (1968), Purine biosynthesis and excretion in Otala (=Helix) lactea: An evaluation of nitrogen excretion potential. Comp. biochem. Physiol., 58B, 579-595.

Stanislawsky, E.; Becker, W. \& Müller, G. (1979), Alterations of free amino acid content in the hemolymph of Biomphalaria glabrata (Pulmonata) in starvation and after infection with Schistosoma mansoni (Trematoda). Comp. Biochem. Physiol., 63B, 477-482.

Teng, Y. S.; Palmieri, J. R. \& Sullivan, J. T. (1979), Changes in the snail carbohydrate and nucleic acid metabolism due to trematode infection. Southeast Asian J. Trop. Med. Public Health, 10, 151-152.

Trede, G. \& Becker, W. (1982), Effects of starvation and infection with Schistosoma mansoni on the release rate of free amino acids (FAA) by Biomphalaria glabrata. Comp. Biochem. Physiol., 73B, 405-409. 